\title{
Development: The Malaysian Experience
}

\author{
Fakhreddin Soltani (Corresponding author) \\ Department of Politics and Government \\ Faculty of Human Ecology, Universiti Putra Malaysia (UPM) \\ 43400, Serdang, Selangor, Malaysia \\ fakhreddinsoltany@gmail.com
}

Jayum A. Jawan

Department of Politics and Government

Faculty of Human Ecology, Universiti Putra Malaysia (UPM)

43400, Serdang, Selangor, Malaysia

Jayum@upm.edu.my

\author{
Ahmad Tarmizi Talib \\ Correspondence: Department of Politics and Government \\ Faculty of Human Ecology, Universiti Putra Malaysia (UPM) \\ 43400, Serdang, Selangor, Malaysia \\ Tarmizi@upm.edu.my
}

Accepted: December 05, 2014

Doi:10.5296/ jpag.v4i4.6914 URL: http://dx.doi.org/10.5296/ jpag.v4i4.6914

\begin{abstract}
Politics in Malaysia is dominated by ethnic considerations; hence, the most critical challenge of development in the country has been the issue of national unity. The Malaysian government has attempted to include all ethnic groups in the process of development regardless of their ethnicity or religion especially since the ethnic riots of 1969. Therefore, the Malaysian government designed economic programs such as the New Economic Policy
\end{abstract}


(NEP) and New Economic Model (NEM) to facilitate this process through state- oriented policies and also include all ethnic groups in the process of development. In fact, Malaysia has followed non-conventional theories of development because of the role of government in the development process. This article seeks to explain the ambitious grand programs of the Malaysian government and demonstrate how these programs have followed non-conventional theories of development.

Keywords: Malaysia, development, NEP, Vision 2020, 1Malaysia, NEM, GTP

\section{Introduction}

Politics in Malaysia has been dominated by ethnic considerations. The total population is about 29.7 million, of which Malays form the biggest ethnic group (50.4\%), and other ethnic groups consist of Chinese (23.7\%), indigenous groups $(11 \%)$, Indians $(7.1 \%)$, and others (7.8\%) ("Malaysia Demographics Profile," 2013). These groups have their own languages and religions. While ethnicity is the main distinctive factor in Malaysian society and government, Islam $(60 \%)$ is the official religion of Malaysia. The other religions in Malaysia include Buddhism, Christianity, Hinduism, Taoism, and other religions (Milne \&Mauzy, 1999). The divergence in religion, culture and language has to some extent complicated the process of development in Malaysia. But regardless of challenges posed by the multi-ethnic situation of the country, Malaysia has been largely a successful country in terms of development and the government has played a critical role in Malaysian development. In fact, the role of the state in the process of Malaysian development has led the country to follow non-conventional theories of development.

Of course, it is important to mention that one of the main reasons for stability and long term success in the process of development in Malaysia is the continuity of economic policies under different administrations. In other words, contrary to other developing countries in which development policies had been drastically altered after changes in administrations, Malaysia has had long term policies and programs that different administrations have committed themselves, and have adhered. Programs such as the New Economic Policy, Vision 2020, and New Economic Model have been inter-related grand programs designed and supported by the government. The policies of Malaysia show that there has been continuity in the process of development. Therefore, the general policy of Malaysia has been one of tolerance and peaceful coexistence. The ethnic riots of 1969 challenged the security of Malaysia, but at the same time made the government more aware of the consequences of ethnic struggles (Yusoff \& Soltani, 2013); as a result, it has made an effort to avoid future ethnic and religious strife through economic reforms that have included all ethnic groups in the process of development.

\section{Development Theories}

Since World War II, development as both an enterprise and a scholarly discipline has evolved significantly. The main stimulus for this evolution was the devastation that war created and the necessity for rebuilding the countries affected by wars. Different institutions such as the International Bank for Reconstruction and Development, that later was known as the World Bank, were created to facilitate this process of development. At the beginning after the end of World War II, industrialization was considered as the main characteristic of development, with its ultimate goal to promote life standards of people in developed societies. For these societies, manufacturing finished goods was considered as an essential process of 
industrialization. After World War II, European countries were weakened and unable to maintain their colonial empires. Asian and African countries achieved independence and were eager to speed up their development. Development was a priority to safeguard their new-found independence through satisfying citizens and gaining their support. Development could help these countries to get the respect and sense of self-dignity they felt had been denied them under colonialism (Rapley, 2007).

The differing needs for development among European countries and newly independent ones divided development studies into two main spheres. Accordingly, two main kinds of theories were formulated, including conventional and non-conventional theories, to explain development process (Peet\&Hartwick, 2009). These conventional theories argue that the capitalist structure as a natural model provides the best method for achieving development. According to conventional theories, economic growth is the best way to reach development. Therefore, accumulation of wealth is considered as the main factor of development and social inequality is the inevitable price of progress. Conventional theories fall under the category of modernization theory which sees development as a unilinear process that western countries have passed through and that other underdeveloped or developing countries should follow the same path.

Non-conventional theories have the opposite contention and argue that capitalism is an unjust structure and cannot be sustained. Social planning and governmental regulation is their solution for market problems. They believe that equating development to economic growth, without attention to its social prices is a dire threat to human life. They posit that development can be achieved through redistribution of production and generally eliminating inequalities. Marxist and neo-Marxist theories, post-structural, and feminist theories are among the main non-conventional theories (Peet\&Hartwick, 2009). Development in thinking, in general, was more paid attention among non-conventional theories. In the twentieth century, theorists of this approach believed in the state as being an agent to push development process. Especially in third world countries, it was accepted that development, especially economic development, needed more state intervention to prepare the appropriate conditions for everyone in the market. This attitude is rooted in the Keynesian approach that influenced third world decision-makers to rely more on state- centric orientations of development (Rapley, 2007).

\section{Malaysian New Economic Policy}

For decades, after independence in 1957, there were no specific grand programs or strategies of development in Malaysia. In fact, the New Economic Policy (NEP) has been the first grand program of the Malaysian government in the process of development. Though the NEP formally ended in 1990, its primary principles were followed in other succeeding programs. The main cause for the introduction of this program was the racial riots of Malaysia in May 13, 1969. The NEP was formulated by the National Operation Council (NOC) in order to eradicate poverty to avoid similar riots in the future (Jawan, 2003). In fact, the, NEP was a state oriented program to decrease economic gaps among Malaysian people regardless of ethnicity.

The program was adopted in 1971 and succeeded by the National Development Policy (NDP) in 1991. Before formulating of the NEP, the main goal of Malaysian development was to strengthen the export market. Despite of significant growth rates, the socio-economic imbalances among the ethnic groups that led to racial riots in 1969 made the politicians deal with problems of inequality through grand economic programs such as the NEP and its succeeding ones. In fact NEP was the stand-point in Malaysian economic policy history that emphasized social aspects of growth as well as economic ones ("New Economic Policy,").

In fact, it was realized that economic growth without paying attention to peripheral groups, especially in countries with many ethnic and religious groups, may lead to disorder. Therefore, the principal goal of NEP was to create national unity. Reducing absolute poverty regardless of race or religion was the pillar of achieving national unity. Economic growth was necessary in order to reach the mentioned goal because it could provide increased economic 
opportunities for the peripheral groups to enable them to move out of poverty through participation in the mainstream economic activities. One of the significant results of the program was that the proportion of households living below the poverty line income declined from 49.3 per cent in 1970 to 16.5 per cent in 1990 and then further fell to 5.1 per cent in 2002 ("New Economic Policy,"). Malaysian programs for dealing with poverty have been focused on development of human resource and improvements in quality of life through greater emphasis on income- increasing projects. The focus of the programs were more on Bumiputeras to make them capable of taking care of themselves, improve standards of education and training, and eradicate imbalances in social and economic spheres ("New Economic Policy,").

Despite the Malaysian economic achievements, it is still a middle-income country. Since more than 25 years ago, Malaysia has been among the few countries that has maintained an average growth rate of $7 \%$ or more per annum. After the Asian Financial Crisis (AFC) in 1998, compared with $8.8 \%$ between 1990 and 1997, the Malaysian growth rate fell to an average of 5.5\% between 1999 and 2008 and it is estimated that the decline of growth rate may continue to hover between $4.3 \%$ and $4.5 \%$. Vision 2020 is a program to enhance the Malaysian standard of life by the year 2020 and achieve developed nation status. Four national transformation programs are planned in Malaysia to reach goals of Vision 2020 are (1) 1Malaysia; (2) the Government Transformation Program; (3) New Economic Model (NEM); and (4) the upcoming 10th Malaysia Plan. 1Malaysia's slogan is "People First, Performance Now" that aims to unite all Malaysians for facing challenges ahead; enhancing public services is the main goal of the Government Transformation Program; inclusiveness and sustainability concepts in NEM are aims of the Economic Transformation Program; and macroeconomic growth targets and expenditure allocation are the goals of the 10th Malaysia Plan (Alias, Rashid, \&Chye, 2010).

\section{Vision 2020}

Vision 2020 (Wawasan 2020 or W2020) is the program that envisions economic, social and government transformation in Malaysia. The first goal of Vision 2020 is to make Malaysia achieve developed nation status by boosting economic development and raising per capita income. Since the Asian crisis, private investment has been stagnant and also the marked presence of government linked companies has discouraged private investors (New Economic Model for Malaysia).

In 1991, Vision 2020 was designed in order to lead Malaysia to be a developed nation by 2020 , in accord with its own unique culture. The priority of W2020 has been to reach economic growth rate of 7 percent per year until 2020. W2020 acknowledged nine challenges of achieving development which are: 1- establishing of united and ethnically integrated society, 2- establishing psychologically self-reliant people in Malaysia who are respected by people of other countries, 3- developing democratic society, 4- establishing ethical society, 5- creating liberal and tolerant society, 6- establishing a scientific and progressive society, 7creating a caring society by emphasizing on a strong family system, 8- establishing of equal distribution of wealth regardless of race or ethnic groups, 9- having competitive economy that leads to prosperous society ("Vision 2020, 1991-2020 ").

The implementation of Vision 2020 is divided into three main phases. The first phase was between the years 1991-2000 and was presented in the Second Outline Perspective Plan (OPP2) of the National Development Policy (NDP) whereby the main goal was to reduce poverty in general. The second phase (2001-2010) started under the Third Outline Perspective Plan (OPP3) of the National Vision Policy (NVP). The main goal here was to create a competitive economy to ensure stability and national unity. The economic crises of 1997/8 and 2008/9 slowed down the process of the two mentioned phases and made decision-makers to believe that the Malaysia has been trapped in the middle-income status and might not be able to achieve the objectives of becoming a developed nation by 2020 . The third phase started with the New Economic Model (NEM) that was launched in 2010 to cover the period 2011 to 2020 ("Vision 2020, 1991-2020"). 


\section{One-Malaysia (1Malaysia)}

1Malaysia was announced by Prime Minister Dato' Seri NajibTunRazak on 16 September 2008 in order to emphasize national unity among the ethnic groups of Malaysia. The eight principles of 1Malaysia are perseverance, a culture of excellence, acceptance, loyalty, education, humility, integrity, and meritocracy (Najib, 1Malaysia). Subsequently, to promote Malaysian standards of life, the BR1M Project was initiated to allocate RM500 to Malaysians with income of less than 3000 Malaysian Ringgit and RM250 to single individuals. Also the second BR1M Project was to allocate more than RM2.5 Billion for Malaysians nationwide (Najib, 1Malaysia)

Moreover, the policy of 1Malaysia is an initiative to create national unity irrespective of race or religious belief. Existence of different racial and religious groups in Malaysia is the national challenge that Najib is attempting to transform into an opportunity through 1Malaysia initiatives. Some projects have been planned in order to decrease the gap between economic classes and consequently strengthen national unity especially among ethnic groups. In this regard, more than 1.5 million people have received treatment at 1 Malaysia clinics by paying just one Ringgit. Another initiative is the Housing Program to help middle- income families buy houses. These examples and other elements in the 1Malaysia initiative are to palliate economic gaps between different classes (Najib, 1Malaysia). Although political transformation also is also included in 1Malaysia programs whereby there is emphasis on strengthening of political reforms and democracy, the focus of the 1Malaysia program is on economic aspects in order to deal with economic frustration, especially among ethnic and religious groups (Najib, 1Malaysia).

\section{Malaysian New Economic Model}

On 2 May 2009, the New Economic Model (NEM) was initiated by Prime Minister NajibTunRazak in which making Malaysia a high income country was the principal objective. In fact, according to NEM, inequality is the biggest challenge Malaysia is facing. The NEM is policy replaced the NEP, which is generally regarded as not having reached its goal of closing the socio-economic gap between different ethnic groups as well as other indigenous Bumiputera communities. Since initiating of NEP, there were still disparity that shows the NEP has remained in various forms behind later programs (Subramaniam, 2014).

In fact the main goal of NEM has been to increase per capita annual income in Malaysia from USD7000 to USD15000 in 2020. High income, sustainability and inclusiveness are three principles of the NEM that were planned to be achieved through encouraging knowledge industries and increasing investment from overseas. According to Najib "High and sustained growth and environmental stewardship can and must go hand-in-hand", which means every one, including future generations should be included through logical policies that ensure safe growth without damaging the precious natural resources and the environment. Therefore the wealth that is going to be created should not exclude anyone in the country. According to him, in order to achieve the mentioned goal, Malaysia should strengthen the private sector and domestic labor, have transparent and competitive economy, enhance public sector, prepare knowledge based infrastructure and finally enhance sources of growth and sustainability of growth. Briefly, sustainability means enjoying satisfactory levels of current consumption while also considering the wellbeing prospects of future generations ("NEM will be led by three principles," 2010). The implementation of NEM is outlined under the Tenth Malaysia Plan and Eleventh Malaysia Plan ("Vision 2020, 1991-2020 ").

The Tenth Malaysian Plan, '10MP', is a comprehensive blueprint that was announced on 10 June, 2010 that was prepared by the Economic Planning Unit (EPU) of the Prime Minister's Department and the Finance Ministry of Malaysia with approval by the Cabinet of Malaysia. The plan allocated the national budget from the year 2011 to 2015 to all economic sectors in Malaysia. The principal goal of the plan, as previous ones, has been to achieve a high income country status by 2020. It has five basic components which are to increase the value of the country's economy; to improve knowledge abilities and innovation, inculcate first-world mentality; to continuously deal with socioeconomic inequalities; to improve level and ability 
of living quality; and to strengthen the institutions needed for implementation.

Actually, the 10MP is a complementary program of the Government Transformation Program and the New Economic Model to achieve the goals of high income, inclusiveness and sustainability. The plan contains the strategies of achieving these mentioned goals ("The Tenth Malaysian Plan 2011-2015," 2010). The 11th Malaysian Plan (11MP) will be announced in June 2015 which will determine the direction of all economic sectors in the country for 2016 to 2020 (Teng, 2013).

\section{Government Transformation Program}

The priorities of the Government Transformation Program (GTP) are to reduce the cost of living, as well as eliminating structural issues preventing the civil service from being as efficient as it could be. In other words it will undertake some reforms in government in order to avoid frustration among Malaysian citizens. It has six principal goals to achieve, namely: Reducing crime, Fighting corruption, Improving student outcomes, Raising living standards of low-income households, Improving rural basic infrastructure, and Improving urban public transport. In short the main goal of GTP is to make some reforms in governmental structures in order to provide better public services to citizens ("Malaysia Government Transformation Programme (GTP); roadmap towards Vision 2020 unveiled," 2010).

Therefore, according to GTP, significant improvements start through transformations in governmental structures as the primary facilitator of development. In other words, first of all, improvement in government is necessary for reducing crime and corruption, improving education, rural basic infrastructure and urban public transport, and boosting the incomes of low- income households in order to attain Malaysian development ("GTP Roadmap, Chapter 14: Transforming Malaysia,").

\section{Conclusion}

Malaysia is placed in a unique situation and therefore has experienced a unique process of development. Though Malaysia has been one of the most successful countries in the process of development, she has been facing challenges of national unity. Therefore, the Malaysian government has played a significant role in dealing with the challenges confronting this process of development. Non-conventional theories are more appropriate to explain the Malaysian process of development because the government has played a critical role in the process of development in order to avoid social fallout due to economic development. After the racial riots of 1969, grand programs were designed for economic development and also to include all social groups in the process. The focus of the programs was to increase income of Malaysians and make reforms in political structure in order to avoid future racial riots, as what had happened in 1969. After more than four decades, the outcomes of these attempts show that these programs have been successful. The main reason for this success has been the continuity of programs without interruption for political reasons. In fact all the different administrations have committed themselves to the same underlying logic that has acted as the underpinning element in the process of development.

\section{References}

1Malaysia. $\quad$ Retrieved $\quad 10, \quad 5, \quad 2014, \quad$ from http://www.1malaysia.com.my/en/my-record/1-malaysia/

Alias, N. Z., Rashid, M. A. A., \&Chye, J. F. K. (2010).New Economic Model - Towards Realising Vision 2020: Malaysian Rating Corporation Berhad (MARK)o. Document Number)

GTP Roadmap, Chapter 14: Transforming Malaysia. Retrieved 10, 5, 2014, from http://www.pmo.gov.my/GTP/index.php

Jawan, J. A. (2003). Malaysian Politics and Government.Shahalam: Karisma Publications.

$\begin{array}{llll}\text { Malaysia Demographics } & \text { Profile. } & \text { (2013). from }\end{array}$ http://www.indexmundi.com/malaysia/demographics_profile.html---Malaysia 


\section{Macrothink}

Journal of Public Administration and Governance

ISSN 2161-7104

Malaysia Government Transformation Programme (GTP); roadmap towards Vision 2020 unveiled. (2010). Retrieved 15, 5, 2014, from http://voyager8.blogspot.com/2010/01/malaysia-government-transformation.html

Milne, R. S., \&Mauzy, K. D. (1999).Malaysian Politics under Mahathir. New York: Routledge.

NEM will be led by three principles. (2010).The Star Online. Retrieved 27, 4, 2014, from http://www.thestar.com.my/story.aspx/?file $=\% 2 \mathrm{f} 2010 \% 2 \mathrm{f} 3 \% 2 \mathrm{f} 31 \% 2 \mathrm{fneweconomicmodel} \% 2$ f5968223\&sec=neweconomicmodel

New Economic Model for Malaysia. National Economic Advisory Council (NEAC)o. Document Number)

New Economic Policy. Retrieved 15,5 2014, from http://www.epu.gov.my/en/dasar-ekonomi-baru

Peet, R., \&Hartwick, E. (2009).Theories of Development: Contentions, Arguments, Alternatives (2 ed.). New York, NY: The Guilford Press.

Rapley, J. (2007). Understanding development: theory and practice in the third world (3 ed.). Colorado: Lynne Rienner Publishers, Inc.

Subramaniam, P. (2014). Economic inequality remains the 'biggest' challenge. Retrieved 20, 6, 2014, from http://www.themalaymailonline.com/malaysia/article/pm-economic-inequality-remains-the-bi ggest-challenge

Teng, L. J. (2013). 11th Malaysia Plan rollout in June 2015.from http://www.thesundaily.my/news/884431

The Tenth Malaysia Plan 2011-2015. (2010). Retrieved 25, 5, , 2014, from http://www.pmo.gov.my/dokumenattached/RMK/RMK10_Eds.pdf

Vision 2020, 1991-2020 Retrieved 20,5, ，2014, from http://www.epu.gov.my/en/wawasan-2020-1991-2020

Yusoff, M. A., \&Soltani, F. (2013).Replicating of Domestic Security Policy in Malaysian Foreign Policy.Asian Social Science, 9(2), 115-120. 